\title{
TRADUÇÕES
}

\section{UMA PASSAGEM DE PORFÍRIO RELATIVA AO ŚIVA ANDRÓGINO DOS BRAMANES DA ÍNDIA}

Joachim Lacrosse*

RESUMO Em um fragmento do Péri Stugos consagrado aos Indianos (376F Smith), que se baseia em um testemunho de Bardesano redigido próximo a 220 d.C, Porfírio menciona a existência de uma estátua representando um deus andrógino. Essa passagem é um traço interessante do tipo de conhecimento que se podia ter em Roma sobre as religiões da Índia. $O$ contexto do relato é romano, mas a citação de Bardesano comporta elementos especificamente indianos. A descrição do santuário evoca um local de culto shivaísta. Particularmente, a estátua corresponde, traço por traço, a uma manifestação importante do deus Śiva: Ardhanārīśvara, o "Senhor metade fêmea", símbolo da unidade das funções masculina (concepção, princípio) e feminina (engendramento, energia) do divino. O tema da dualidade emergindo da unidade indiferenciada e voltando a ela é um traço comum do neoplatonismo e dos pensamentos da Índia. Em um discípulo de Plotino e no contexto sincrético da época, a menção entusiasta de uma tal representação da unidualidade divina poderia ser explicada por afinidades ideológicas, sem que se deva falar de "influências".

Résumé Dans un fragment du Péri Stugos consacré aux Indiens (376F Smith), qui se base sur un témoignage de Bardesane rédigé vers 220 après J.-C., Porphyre mentionne l'existence d'une statue représentant un dieu androgyne. Ce passage est une trace intéressante du type de connaissances

* Chargé de recherches F.N.R.S., Centre de Philosophie ancienne de I'U.L.B. Un passage de Porphyre relatif au Śiva androgyne chez les brahmanes d'Inde. Révue de Philosophie Anncienne, 20, n. 2 (2002), p. 37-56. Artigo traduzido por Elisa Franca e Ferreira <elisafferreira@yahoo.com.br>. 
que l'on pouvait avoir, à Rome, au sujet des religions de l'Inde. Le contexte $d u$ récit est romain, mais la citation de Bardesane comporte des éléments spécifiquement indiens. La description du sanctuaire fait penser à un lieu de culte sivaite. En particulier, la statue correspond trait pour trait à une manifestation importante du dieu Śiva: Ardhanārīshvara, le "Seigneur à moitié fermme", symbole de l'unité des fonctions masculine (conception, principe) et féminine (engendrement, énergie) du divin. Le thème de la dualité émergeant de, et retournant à l'unité indifférenciée est un trait commun du néoplatonisme et des pensées de l'Inde. Chez un disciple de Plotin, et dans le contexte syncrétique de l'époque, la mention enthousisaste d'une telle représentation de l'unidualité divine pourrait être expliquée par des affinités idéologiques, sans qu'on doive parler d' "influences".

Em um artigo recente, coloquei em evidência três documentos porfirianos que tratam da questão difícil e controversa das influências indianas sobre o neoplatonismo e que permitem estabelecer, no mínimo, a existência de um "sonho indiano", de uma relação longínqua e onírica com a Índia, em Plotino e Porfírio. ${ }^{1} \mathrm{O}$ primeiro é uma célebre passagem que concerne à viagem não realizada de Plotino em direção à Índia e à Pérsia (Vie de Plotin, III, 6-24). O segundo é um longo extrato do tratado Da abstinência (IV, 16, 9 a 18, 3) onde está em questão a distinção entre "brâmanes" e "samaneus" - estes últimos correspondem, sem dúvida, a ascetas budistas. O terceiro é uma citação de Agostinho declarando - na Cidade de Deus (X, 32), referindo-se ao tratado perdido Do retorno da alma - que Porfírio tinha o projeto de realizar uma síntese entre o platonismo, o ensinamento revelado dos caldeus e os "costumes e ensinamentos dos indianos" (Indorum mores ac disciplina).

O presente estudo tem por objetivo completar esse dossiê acrescentandolhe um quarto testemunho freqüentemente despercebido. ${ }^{2}$ Trata-se de um fragmento do tratado Sobre o Estige, conservado graças a Estobeu (I, 3, 56) ${ }^{3}$

1 Le rêve indian de Plotin et Porphyre. Revue de Philosophie Ancienne, XIX/I, 2001, p. 79-97.

2 Ele não é mencionado por nenhum dos comentadores que estudaram as relações entre o neoplatonismo e a Índia, nem mesmo por O'Meara, "Indian Wisdom and Porphyry's Search for a Universal Way", em R. B Harrris (ed.), Neoplatonism and indian Thought, Albany (N.Y.), 1982 (repr. Delhi, 1992), p. 5-26, que, no entanto, se interessou pela relação particular de Porfírio e a Índia.

3 Fr. 376 de Porfírio na edição de A. Smith (Porphyrii philosophi fragmenta, Stuttgart-Leipzig, 1993, p. 4474451). Encontramos também como fragmento de Bardesano (F1) em Jacoby (FGrH, n. 719, $111 \mathrm{C}, \mathrm{p}$. 643-645) e em B. Breloer e F. Brömer (Fontes historiae religionum indicarum, Bonn, 1939, p. 133-136). Uma 
e no qual estão em questão dois lagos sagrados onde os indianos realizam provas de virtude sob a forma de ordálias pela água. O interesse principal desse texto é que encontramos a descrição de uma estátua venerada pelos brâmanes, representando um deus andrógino; a descrição corresponde, quase traço por traço, a uma figura bem conhecida do deus Śiva. A menção dessa representação divina, em um cidadão romano do terceiro século, é particularmente única e notável, tanto do ponto de vista dos conhecimentos greco-romanos sobre a Índia quanto da história da estatuária indiana. Considerarei, um após o outro, (1) o contexto histórico e literário, (2) os aspectos iconográficos, (3) a interpretação filosófica e (4) o alcance sincrético dessa descrição.

1. Em qual contexto a descrição da estátua inscreve-se? Globalmente, o terceiro século d.C parece corresponder, no Império romano, a um período de aquisição de novos conhecimentos limitados, mas freqüentemente confiáveis, sobre o tema do modo de vida, dos mitos, dos símbolos, dos rituais e, às vezes, da doutrina dos gimnosofistas da Índia. Não nos contentamos mais somente em retomar os testemunhos dos companheiros de Alexandre, o Grande, ou aquele de Megasteno, mas tentamos também acrescentar a eles informações mais recentes relatadas pelos viajantes ou diplomatas. Textos da mesma época, de Clemente de Alexandria, Filostrato de Tiro ou ainda Hipólito de Roma, confirmam essa tendência à renovação de informações. ${ }^{4}$ Os primeiros neoplatônicos dificilmente podiam escapar a essa tendência: Alexandria é a cidade onde Plotino seguiu o ensinamento de Amônio, Tiro é o local de nascimento de Porfírio, e Roma é a cidade em que Plotino abriu sua escola, tendo encontrado Porfírio. ${ }^{5}$

Como na passagem do tratado Da abstinência sobre os indianos, Porfírio declara explicitamente que sua fonte é o célebre gnóstico sírio Bardesano, ${ }^{6}$ o qual teria encontrado uma embaixada indiana sob o reino do imperador

nova edição independente com tradução e comentário dos fragmentos do Peri Stugos será publicada em breve na Itália por Christiano Castelletti (Milan, 2003), a quem agradeço aqui por ter me permitido consultar suas notas e documentos. Agradeço também Roger-Pol Droit por ter me cedido o texto de uma comunicação inédita que ele apresentou no C.N.R.S (U.P.R. 76) sobre "L'Inde de Porphyre. Lumières et obscurités", em dezembro de 2000.

4 Sobre esse ponto, ver, entre outros, R. GOOSENS. "Un texte grec relatif à l'aśvamedha", Journal asiatique, oct. déc. 1930, p. 280-285; J. FILLIOZAT, "La doctrine des brâmanes d'apres saint Hippolyte", Revue de l'histoire des religions, 130, 1945, p. 59-91; A. DIHLE, "The Conception of India in Hellenistic and Roman Literature", Proceedings of the Cambridge Philological Society, 190, 1964, p. 15-23; 1. Filliozat, "La valeur des connaissances gréco-romaines sur l'Inde', em Jornal des Savants, avril.juin 1981, p. 97-135; J.W. Sedlar, India and the Greek World, Totowa, 1981. Contra, G. Ducœur, Brahmanisme et encratisme à Rome au III' siècle, Paris, 2001. Ver também os trabalhos de C. Muckenstum Poulle sobre os textos da época imperial relativos aos gimnosofistas.

5 Ver o artigo de J.J O'Meara citado acima, n. 2, e meu estudo citado n. 1.

6 Sobre Bardesano, ver notadamente H.J.W. Drijvers, Bardesanes of Edessa, Assen, 1966 e J. Teixidor, "Bardesane de Syrie", em R. Goulet (dir.), Dictionnaire des philosophes antiques, t. 11, 1994, p. 54-63. 
Heliogábalo (217-222). Porfírio nascera em 234 e tem verdadeiramente o relato de Bardesano sob os olhos quando escreve as duas passagens. ${ }^{7}$

Nos dois textos, Porfírio parte de um fato tipicamente greco-romano - as virtudes do vegetarianismo para as elites intelectuais, por um lado, e o poder das águas do Estige, por outro - para procurar um tipo de confirmação desse fato nos costumes dos povos renomados pela sua sabedoria. Fazendo isso, ele expõe, no entanto, informações originais e autênticas sobre os Indianos invocados assim..$^{8}$

No início, o fragmento do tratado Sobre o Estige consagrado aos indianos (376 Smith) é, então, uma digressão de Porfírio a partir das propriedades particulares emprestadas às águas do rio dos infernos. Essas são reputadas por punir aqueles que ousariam perjurá-las; elas são, de alguma maneira, as garantias da verdade (cf. 374 F). Porfírio estabelece uma ligação com uma prática indiana que consiste em submeter certos indivíduos a uma ordália (dokimastérion) pela água de dois lagos sagrados. O primeiro lago é utilizado para confundir os criminosos ou seus acusadores: eles são levados para a margem da água para que atravessem o lago, onde são submergidos, depois repescados e entregues aos seus opositores se eles persistem em negar seus crimes ou em caluniar alguém, enquanto a água permanece na altura dos joelhos, se eles forem sinceros. O segundo lago, situado no fundo de uma grande gruta, é utilizado pelos brâmanes para constatarem suas virtudes ou, se quisermos, para se assegurarem sobre o estado de seus karman (orthòs bios, 1.28). No fim desse lago, encontra-se uma porta que se abre apenas para aqueles que permaneceram ao abrigo do vício. Atrás da porta, os homens virtuosos encontram uma fonte de água clara e perfeitamente potável. A estátua do deus andrógino vigia a entrada da gruta que leva, na obscuridade, a esse segundo lago e a essa fonte.

Esse relato tem vários paralelos romanos. O episódio das duas ordálias e da gruta parece com o relato que se encontra no fim do grande romance de Aquiles Tácio, Clitofonte e Leucipe, onde se trata de colocar à prova duas

7 É preciso notar que os dados desses fragmentos de Bardesano não coincidem em nenhum ponto, nem mesmo sobre o nome do chefe da delegação indiana nomeado "Damadamis" no De abstinentia e "Sandales" no Péri Stugos. Propomos corrigir os dois nomes para "Dandamis" de acordo com o nome de um célebre gimnosofista encontrado pelos companheiros de Alexandre o grande (ver M. Patillon, A. Ph. Segonds e L. Brisson, Porphyre. De l' abstinence, IV, Paris, 1995, p. XXXIX, e n. 260 p. 88). Essa correção anacrônica não me parece, entretanto, necessária, pois não temos razão para duvidar da autenticidade desses nomes. Tratar-se-ia simplesmente de dois personagens diferentes fazendo parte da mesma embaixada.

8 Como nota R. -P. Droit, em sua comunicação citada acima, n. 3, há "nos dois casos um movimento duplo de inserção do testemunho fornecido pelos dados indianos em uma análise que os ultrapassa e da atenção dada por eles mesmos às informações desconcertantes ou exóticas transmitidas por Bardesano". 
mulheres. A primeira, Leucipe, ao som melodioso de uma siringe, sai ilesa da prova da gruta de Pã, para onde se levam as mulheres cuja virgindade é colocada em dúvida. A segunda, Melita, passa com sucesso pela prova das águas do Estige, onde se coloca à prova uma mulher acusada em uma história de amor. Para a cortesã Melita, a água permanece no lugar e não sobe o mínimo acima de seu nível comum, isto é, como em Porfírio, na altura dos joelhos (VIII, 6, 12 sq. e VIII, 12-14). A proximidade entre os dois textos é impressionante. ${ }^{9}$ Notamos que é somente quando Porfírio cita Bardesano literalmente que essa semelhança com o romance de Aquiles Tácio se atenua, afastado o elemento rupestre.

Outro paralelo romano que concerne, dessa vez, diretamente aos indianos, reside na menção de uma fonte de água clara detida pelos brâmanes. Porfírio, no fim do fragmento (1.90-98), opera uma ligação com Apolônio de Tiane prestando juramento aos brâmanes "pela água de Tântalo com a qual me iniciaram em seus mistérios". É dessa água e dessa gruta dos brâmanes da Índia dos quais Bardesano fala que Apolônio, nos dizeres de Porfírio, deve fazer alusão. ${ }^{10}$ Aliás, sobre o mesmo tema, Dio Crisóstomo (Discours, XXXV, 22), que diz obter suas informações dos viajantes (talvez mesmo do próprio Apolônio), já fala, como Porfírio/Bardesano, de uma "fonte da verdade" que os brâmanes possuiriam: a mais divina das fontes cuja água é tão pura que aquele que a experimenta é incapaz de mentir. Sobre esse ponto, o fragmento 376 de Porfírio parece, então, retomar igualmente uma tradição romana mais antiga que trata de aproximar o testemunho de Bardesano sobre a Índia. O mesmo não ocorre para a descrição da estátua, única em seu gênero e que constitui o aspecto mais original e mais autêntico de nosso fragmento.

2. Vamos agora aos aspectos iconográficos da descrição da estátua do deus andrógino. Porfírio cita Bardesano aqui de modo literal (katà léxin), o que anuncia a exposição de dados especificamente indianos (I. 29-45 e 58$60)$.

9 Como já notamos F. Boll, "Zum griechischen Roman", Philologus, LXVI, 1907, p. 1-15 e E.J. Kroll, "Gott und Hölle", Studien der Bibliothek Warbug XX, 1937, n. 3, p. 348. Perguntamo-nos se Aquiles Tácio, cuja cronologia é muito incerta, inspirou Porfírio ou diretamente Bardesano, ou se é Porfírio que se inspirou em Tácio vendo nele uma semelhança com o relato de Bardesano. É possível também que estejamos na presença de uma tradição que foi, de início, oral - concernente às águas do Estinge -, tradição da qual Porfírio e Tácio fariam eco independentemente um do outro. Sobre essa questão, ver comentário (a ser publicado) de C. Castelletti (cf. acima, n. 3).

10 Sobre a água de Tântalo, ver PHILOSTRATE, Vie d'Apollonius de Tyrane, m, 25; m, 32; m, 5. Vemos aí Apolônio dividir com os indianos o líquido puro e abundante, contido em uma taça estendida por uma estátua de Tântalo. A terceira passagem corresponde à Carta 77 de Apolônio de Tiane (cf. RJ. Penella, The Letters of Apollonius of Tyrane, Mnemosyne, suppl., 56, Leyde, 1979). 
Eles (os embaixadores indianos) me disseram que também há uma grande gruta natural em uma das mais altas montanhas, quase no meio de terra, na qual se encontra uma estátua medindo aproximadamente dez a doze côvados, estando em pé com as mãos abertas, à maneira de uma cruz. A parte direita de sua face é masculina e a esquerda, feminina. Ocorre o mesmo com o braço direito e o pé direito; logo, toda a parte direita é masculina e a esquerda, feminina, de maneira que o espectador é marcado de estupor por essa compenetração, por ver de modo indivisivel essas coisas dessemelhantes, os dois lados estando em um só corpo. Eles me disseram que sobre a estátua estão gravados o sol sobre o seio direito, a lua sobre o esquerdo, enquanto que sobre os dois braços estão gravados, com arte, o nome de anjos e de outras coisas do universo, como os deuses, as montanhas, o mar; os rios e o oceano, assim como as plantas e os animais, logo, tudo que existe. [...] Eles diziam que a estátua tinha sobre a cabeça a imagem de um deus sentado sobre uma espécie de trono. [...]

Essa representação divina corresponde sem dúvida alguma, na iconografia religiosa hindu, à manifestação de Śiva sob a forma de Ardhanārīśhvara, ${ }^{11}$ o "Senhor metade mulher", tão conhecido pelo nome de Ardhanaranarī, "metade homem, metade mulher". ${ }^{12}$ Esse deus andrógino é e foi freqüentemente esculpido em pedra ou em bronze e também representado em moedas na Índia. Encontramo-lo por toda a Índia, do norte ao sul e do leste ao oeste, nos templos e nos museus. ${ }^{13}$ Com Națarāja, o "Rei da dança", Ardhanārīśhvara constitui, ainda hoje, uma das formas mais populares do culto de Śiva, uma representação que exprime - em termos humanos, tendo recorrido ao esquema da diferença sexual -, uma estrutura metafísica universal, jogando sobre a unidade e a dualidade. Ardhanārīśhvara simboliza a união do princípio divino, Śiva, e de sua energia feminina ou śakti, personificada freqüentemente por Pārvatī. ${ }^{14}$

11 Peço desculpas aos indianistas pela transliteração aproximativa dos termos sânscritos.

12 Sobre o tema de Ardhanārīśhvara, existe um estudo recente e muito completo de N. Y ADAV, Ardhanarisvara in Art and Literature, Delhi, 2001. Ver também Goldberg, "Ardhanarisvara in Indian Iconography. A New Interpretation", East and West, 49, 1999, p. 175-187. Não pude consultar a obra do mesmo autor, Ardhanarisvara in Indian and Feminist Perspective, New York, 2002.

13 Ver as numerosas representações em N. Yadav, op. cit., passim. Encontramos também belas fotos de Ardhanāríśhvara na Internet, por exemplo, aquela de uma escultura no seguinte site: <www.eiu.edu/ nonwest/images/India_images/pages/Ardhanarisvara.htm>. Ver igualmente S. Kramrisch, Manifestations of Shiva, Philadelphie, 1981, p. 18-20; G. Liebert, Iconographic dictionary of the Indian religions, Brill, 1976, p. 21; p.z. Pattabiramin, "Notes d'iconographie dravidienne, Ardhanarishvaramurti", Arts asiatiques, VI, 1959, p. 13-19; C. Sivaramurti, "Shiva androgyne", em L'art en Inde, Paris, 1999 (1974). Existe no Himachal Pradesh, em Mandi, um templo consagrado exclusivamente à Ardhanārīśhvara.

14 O casamento de Śiva e Pārvatī é outra representação iconográfica dessa união, assim como o linga (phallus) par de seu yoni (órgão feminino). Os outros grandes deuses da trindade hindu também são 
O testemunho de Bardesano confirma as fontes indianas que atestam que, nessa īpoca, a figura de Śiva tinha se tornado uma forma privilegiada da divindade suprema e Ardhanārīśhvara uma de suas principais manifestações. ${ }^{15}$ Se compararmos o fragmento de Porfírio com as estátuas indianas, a descrição de Bardesano concorda com a iconografia shivaísta em numerosos pontos, sem que seja possível, por razões cronológicas, identificar precisamente tal sítio, local arqueológico ou tal escultura conhecidos hoje. Vários elementos devem reter nossa atenção.

Antes de tudo, trata-se de uma grande gruta situada em uma montanha alta. Tais grutas naturais transformadas em templos e guardadas por uma estátua divina são muito numerosas na Índia, particularmente no contexto shivaísta. ${ }^{16}$ Ademais, a lenda e o culto de Śiva são estreitamente associados às montanhas, aos sonhos narcóticos do deus nas alturas do monte Kailāsa (Himālaia) e à sua união com Pārvatī, a "filha das montanhas". Aliás, Śiva é considerado pelos devotos, entre outros epítetos, como a fonte de todos os rios, o senhor das montanhas e os senhor das grutas. ${ }^{17}$

O tamanho da estátua (5 a 6 metros) é verossímil, e o simples fato de que esse tamanho seja mencionado indica a grande precisão do testemunho de Bardesano. Outro ponto importante é o corte vertical da estátua do qual não encontramos equivalente na iconografia própria ao mundo greco-romano. ${ }^{18}$ Em muito raras exceções, ${ }^{19}$ a parte direita de Ardhanārīśhvara é sempre masculina, e a esquerda, feminina, como é o caso da estátua descrita pelos embaixadores indianos. Assim, Śiva, mesmo quando não é representado sob a forma andrógina, é freqüentemente ornado com dois brincos, um masculino na orelha direita e um feminino na esquerda.

associados às suas śakti: Sarasvatī a Brahmā e Lakșmī a Viṣnu.

15 Essa forma de Śiva aparece, sem dúvida, aproximadamente no final do II ap J.-C, em que ela é representada sobre uma moeda do tempo de Kanișka III (176-210). A estátua conservada mais antiga de Ardhanārīśhvara data igualmente do segundo ou terceiro século de nossa era, isto é, na época em que ocorreu o encontro de Bardesano e os embaixadores. Ela foi encontrada em Mathurā em Uttar Pradesh e está exposta hoje em Londres, no Victoria and Albert Museum. Sobre esse ponto, ver N. Yadan, op. cit, p. 3 (sobre a estátua encontrada em Mathurā), 13 (sobre a moeda do tempo de Kanishka III) e 14 (sobre a importância do testemunho de Bardesano para a datação da introdução do culto de Ardhanārīśhvara).

16 Podemos observar estátuas de Ardhanārīśhvara em tais grutas sobre o sítio de Elefanta (perto de Bombay, em Mahārāștra) e em Mogalarajapuram (perto de Vijayawada, em Andhra Pradesh). A estátua que se encontra sobre esse último sítio é considerada a mais antiga representação rupestre de Ardhanārīśhvara e ela, dizem, é a única em seu gênero em toda a Índia do sul.

17 Cf. D. Pattanaik, Shiva. An Introduction, Bombay, 1997, p. 100.

18 Como nota C. Castelletti em seu comentário, a ser publicado (cf. acima, n. 3), o andrógino ou hermafrodita, na Grécia e em Roma, é um ser de um dos dois sexos que apresenta características do outro sexo (vários exemplos literários em M. Delcourt, Hermaphrodite. Mythes et rives de la bisexualité dans l'Antiquité classique, Paris, 1958). Todavia, encontramos tais representações "simétricas" da androginia em certos alquimistas da Idade Média (cf. A. Roob, Le musée hermétique, Stuttgart, 1997, p. 456, 462 e 463).

19 Ver N. Yadav, op. cit., p. 9. 
Ocorre o mesmo para as bijuterias e ornamentos de Ardhanārīśhvara: à esquerda, braceletes ao longo de seu braço e em volta de seu tornozelo, anéis nos dedos, um espelho ou um lótus na mão, enquanto que, segundo os casos, seu corpo ou suas vestimentas coloridas indicam ostensivamente seu pertencimento à espécie feminina; à direita, sua mão agita orgulhosamente um tridente; ele é freqüentemente vestido com uma pele de tigre, ornado com um crânio ou com serpentes; seu corpo viril, seu bigode ou sua barba permitem, tudo tão claramente, determinar que se trata de um ser do sexo masculino.

Nas representações de Ardhanārîśhvara, o sol não é esculpido sobre seu tronco masculino, não mais que a lua não é gravada sobre seu seio esquerdo, feminino, como diz nosso texto. Entretanto, a lua é às vezes representada sobre o diadema de Śiva. Por outro ponto de vista, a literatura sânscrita associa freqüentemente a beleza feminina à lua, mesmo se o termo sânscrito para "lua" é masculino (candra). Sobretudo o yoga kuṇdalinī identifica mais precisamente a parte esquerda do corpo humano com a lua e a feminilidade, enquanto a parte direita é caracterizada pelo sol (sūrya) e pela força masculina. ${ }^{20}$

No que diz respeito aos ornamentos gravados com arte sobre a estátua, os entalhadores de pedra indianos deixaram vários painéis representando cenas mitológicas ou épicas nas quais se acumulam vários seres naturais e sobrenaturais. ${ }^{21}$ Os "anjos" dos quais trata são provavelmente os deuses védicos tornados divindades de segundo nível, os deva (s), no contexto do deus Śiva como deus supremo, İśhvara. Os animais associados a Śiva são principalmente a cobra, o pavão, o touro, o antílope e os cães. O lótus, as florestas, as montanhas, os rios e as grutas são freqüentemente gravados finamente sobre os braços da estátua. O fato de gravar "tudo que existe" sobre uma tal estátua explica-se pelo fato de Śiva ser o mestre do universo, a divindade suprema. ${ }^{22}$

Enfim, os embaixadores indianos mencionam um deus sentado sobre uma espécie de trono, representado sobre a cabeça de Ardhanārīśhvara. Se Śiva está às vezes sentado sobre um trono, a divindade que se encontra sobre sua cabeça poderia ser a deusa do rio Gangā, freqüentemente representada como uma mulher velha em cólera que reside em seus cabelos emaranhados. ${ }^{23}$

20 Ver abaixo.

21 Ver, entre vários exemplos, a representação de Ardhanārīśhvara gravada em pedra em Elefanta (N. Yadav, op. cit., pl. 61A p. 104).

22 Cf. Lassen, Indische Altertumskunde, Berlin, 1858, t. III, p. 348 sq.

23 Sobe essa representação de Gañgā, ver D. Pattanaik, op. cit., p. 97 sq., e N. Yadav, op. cit., p. 136. Lassen, loc. cit., também pensa que se trata de Gañgā. 
Ademais, os indianos encontrados por Bardesano contam, sobre o tema da estátua, toda uma série de anedotas e de narrativas que coincidem bem com o folclore e o espírito que anima os locais de culto na Índia. O material utilizado, que se assemelha a um tipo de madeira inflexível e incorruptível, não corresponde a nenhum material conhecido (1.48-54) ${ }^{24} \mathrm{~A}$ estátua, contam ainda os indianos, sangra quando se tenta arrancar-lhe um cabelo e transpira muito em altas temperaturas, inundando todo o território em volta dela (1. 5458 e $60-64) !^{25}$

Os brâmanes, dizem eles, enfim (cf. 1. 64-90), juntam-se em uma data fixa nesse local para celebrações - alguns vivem aí todo o ano, e outros vão ocasionalmente ver seus amigos, contemplar a estátua ou provar seus karman provando uns aos outros e a eles mesmos que são capazes de passar pela porta que leva à fonte da verdade. Os que fracassam confessam seus erros, detêm-se longo tempo para orar e jejuam durante um tempo considerável. Os detalhes esculpidos que a estátua de Ardhanārīśhvara omite parecem também alimentar várias discussões entre os brâmanes, que rivalizam em engenhosidade para interpretar o significado global da representação. Eis aí um contexto que corresponde ainda hoje ao ambiente que cerca vários santuários e lugares de peregrinação hindus.

3. Quais são as interpretações, na Índia, dessa manifestação de Śiva sob a forma de andrógino? Evocando essa estátua de Ardhanārīśhvara, Porfírio acentua um traço importante e bem conhecido das tradições religiosas indianas: a união cósmica de um princípio masculino de concepção e de uma energia feminina de engendramento. Trata-se de um elemento essencial da metafísica e da cosmologia védicas e pós-védicas. O Rrg-Veda já evoca os "parentes universais" e a mãe deusa é sempre considerada, na Índia, como o protótipo da energia ou matéria cósmica (Prakrti) que é a contrapartida do homem primordial, da alma cósmica (Puruṣa). O mundo inteiro está contido na união desses dois princípios. ${ }^{26}$

Notamos que esse elemento da cosmologia hindu não era conhecido no mundo greco-romano, mesmo se nosso fragmento é o único a mencionar explicitamente o símbolo do andrógino. O próprio Porfírio declara, em seu tratado Da abstinência (IV, 17, 3), que os brâmanes, contrariamente aos samaneus, descendem todos de um único pai e de uma única mãe. Filostrato

24 Para Lassen, loc. cit., a matéria desconhecida é talvez um tipo de madeira.

25 Como nota R. -P. Droit (enunciação citada acima, n. 3), "estátuas vivas, consideradas como tais, levadas em procissão, arejadas, deitadas, vestidas, alimentadas, etc., há delas em todo lugar na Índia".

26 N. Yadav, op. cit., p. 8 e 113. 
também faz alusão a isso na biografia de Apolônio de Tiane, quando este último interroga seus interlocutores sobre a natureza masculina ou feminina do universo. Unindo-se a ele mesmo, o indiano Larchas responde: o universo produz os atos de um pai e de uma mãe e ele se une a si mesmo por um amor que faz sua unidade e sua coerência enquanto suas partes também se prestam a tudo que engendra e a tudo que produz (Vie d'Apollonius de Tyane, III, 34).

A figura de Ardhanārîśhvara, que constitui de alguma maneira uma recuperação desse tema no contexto do culto de Śiva como deus supremo, deu lugar a um grande número de relatos mitológicos e de interpretações deônticas, cosmológicas ou filosóficas. No Mahābhārata (XIII, 14 e 146), a união dos sexos simboliza a associação das funções de criação e de destruição na figura do senhor Rudra, a forma primitiva de Śiva. O poeta Kālidāsa (séculos IVV) evoca várias vezes a união de Śiva e Pārvatī. A união em um único corpo é o símbolo do amor indivisível que as esposas provam (Kumārasambhava I, 50 e VII, 28; Mālavikāgnimitra I, I). Śiva e Pārvāti, diz, não podem ser concebidos separadamente como as palavras e seus significados estão em constante associação. Eles são Prakrti e Puruṣa unidos como parentes do universo (Raghuvaíśa I, 1). ${ }^{27}$

Nos Purạnas (textos mitológicos compostos entre o quinto e o oitavo séculos sobre a base de tradições mais antigas), conta-se, com numerosas variações, como Śiva e Pārvatī são levados a se unirem para terem somente um corpo ou, ao contrário, a se separarem depois de terem sido criados juntos com um só corpo. Ora Śiva suplica a Brāhma que pare com seus tormentos, o que o deus criador faz ordenando à parte feminina que se separe, o que constitui a passagem da copulação para a criação (Śiva-Purāna, III). Ora Śiva engendra Ardhanārīśhvara como seu filho, destruindo tudo e recriando Brāhma a partir do lado masculino e Viṣnu a partir da parte feminina (LingaPurāna). Ora é Brahma que solicita Rudra que se separe em homem e mulher ou Parvati que suplica ao seu esposo para morar com ele em um único corpo (Skanda-Purāna) ou, enfim, Śiva que, em um impulso de amor conjugal, permite que Pārvatī adquira a metade de seu corpo, sinal de sua fidelidade (Kālikā-Purāna, XLV, 17-38). ${ }^{28}$

Nas seitas ditas "shivaístas" e "shaktístas", Ardhanārīśhvara combina um aspecto erótico e conjugal e um aspecto místico de união com o divino. $\mathrm{O}$ tantrismo vê aí o sinal de que Śiva não é nada sem sua śakti, o que significa que a sabedoria não pode se mover sem a potência e que é preciso honrar os 
dois princípios, masculino e feminino, para chegar à imobilização das funções do ser humano, que são a respiração, a emissão seminal e o pensamento. ${ }^{29} \mathrm{O}$ misticismo indiano impregnado pelo yoga associa a figura de Ardhanārīśhvara à Kuṇulalinī, a serpente feminina que é a energia divina (śakti) em seu estado de repouso. Essa energia é experimentada no corpo humano como força feminina, masculina e andrógina. A parte esquerda do corpo, associada à lua e à feminilidade, é o conduto da energia física e emocional. A parte direita, masculina, associada ao sol, é o conduto da energia intelectual e mental. O principal conduto que passa pela coluna vertebral é o conduto da energia "andrógina" kuṇdalinī a qual é liberada pela prática do yoga. ${ }^{30}$

A maior parte dos sistemas filosóficos ou darśana (s) deram sua própria interpretação dessa figura de Śiva em função das premissas de seu próprio pensamento. Assim, o Vedānta "não dualista' insiste na união dos dois princípios, enquanto o Sāmkhya, "dualista", explora a bipolarização. Para o Advaita-Vedānta, Ardhanārīśhvara exprime, de modo simbólico, o fato de que a ilusão cósmica (māyā) existe em Brahman e no Ātman, como o calor existe no fogo. A existência separada de um princípio e de uma energia criadora é uma ilusão de dualismo, uma oposição enganadora que convém retirar unificando esses dois componentes do Absoluto uno e indiferenciado (Śan்kara, Śatapatha-brāhmaṇa, XIV, 4, 2, I e Bhrad-ār up., III, 1). Quanto ao Sāmkhya, ele reconhece dois princípios, o Eu ou o Puruṣa (pólo masculino) e a Força eterna, o germe prolífico ou Prakrti (pólo feminino). Ele, então, considera a criação como fundada sobre um substrato neutro que se divide em substância (masculina) e em energia (feminina), cuja união é indispensável antes de toda criação. ${ }^{31}$

O andrógino Ardhanārīśhvara simboliza, então, na literatura sânscrita, sucessivamente, o caracter assexuado do deus supremo ou do substrato antes da criação, a universalidade, a relação entre Śiva e sua śakti, a fidelidade conjugal, o desejo primordial que está na fonte do movimento da vida, a igualdade e a complementaridade das funções masculina e feminina, ou ainda, a associação dos condutos nervosos masculinos e femininos no corpo humano.

Essa unidade binária simbolizada pelo andrógino dá lugar a várias especulações caracterizadas por um modo de pensamento henológico. Os princípios masculino e feminino são considerados como complementares e só

29 Ibid., p. 127 sq., e M. Eliade, Méphistophélès ou l' androgyne, Paris, 1962, p. 170 sq.

30 S. Subramuniyaswami, Dancing with Shiva, Delhi, 1996. p. 685-686, 751. 766-767 e 803-804.

31 N. Yadav, op. cit., p. 131 sq. 
podem ser colocados isoladamente sob o modo da ficção. Ao mesmo tempo, cada um mantém sua própria identidade, dependendo do outro sem lhe fazer sombra. Tão inseparáveis como o ar e o vento ou como o fogo e o calor do fogo, Śiva e sua śakti representam a harmonia e o equilíbrio dinâmico de toda uma série de conjuntos opostos: substância e energia, ser e consciência, deliberação e expressão, significação e ação, tempo e espaço, objeto e sujeito, fogo e receptáculo, corpo sutil e corpo grosseiro, distanciamento ascético e presença no mundo, etc. ${ }^{32}$

4. O que é, enfim, o alcance sincrético dessa descrição? Por que Porfírio cita integralmente essa parte do relato de Bardesano que não tem, contudo, quase nada a ver com as águas do Estige às quais seu tratado é consagrado? A menção de Ardhanārīśhvara é simplesmente o efeito da curiosidade do filósofo neoplatônico para com os costumes religiosos dos povos bárbaros, a conseqüência de um "milagre oriental" característico da época ou ela é também fruto de uma cumplicidade intelectual e de afinidades ideológicas com esse tipo de simbolismo?

Citando Bardesano literalmente, Porfírio exprime com ele sua admiração pela potência simbólica dessa representação divina que permite apreender a unidualidade do princípio pela "compenetração" (sýnkrasis, I. 38) dos opostos. O espectador é marcado de estupor e compreende instantaneamente a individualidade das oposições binárias. Ele vê que, unidas por um só corpo, as duas naturezas, masculina e feminina, não são opostas, mas complementares, ao mesmo tempo diferentes (anomoióteta, I. 38-39) e percebidos de modo indivisível (adiaíretos, I. 38) pela união dos dois aspectos, concepção e engendramento, em uma só entidade.

Sem que seja necessário estabelecer "tecnicamente" uma influência indiana sobre Porfírio ou sobre seu mestre, devemos observar que essa concepção henológica do divino, considerado como unidade binária, apresenta várias semelhanças com o pensamento dos primeiros neoplatônicos, começando por Plotino. Os tratados deste último, as Enéadas, apresentam-se como uma especulação sobre o conjunto das estruturas henológicas que regem os diferentes níveis da experiência metafísica. Encontramos nelas uma teoria da duplicidade da alma, ao mesmo tempo sensível e inteligível, fazendo proceder a vida nos seres sensíveis que ela engendra através de sua conversão impassível em direção aos seres inteligíveis que ela contempla. Em um nível superior de unificação, o intelecto divino ainda exprime essa dualidade, de modo

32 Ver A. Daniélou, Le polythéisme hindou, Paris, 1960, p. 311-313, e N. Yadav, op. cit., p. $122-125$ e $132-$ 133. 
mais intensivo, determinando-se ao mesmo tempo como ser e pensamento, simultaneamente "dois" e "um". O tema da dualidade emergindo da unidade primitiva e indiferenciada e voltando a ela é um traço fundador comum no neoplatonismo e nos pensamentos da Índia.

Em compensação, do ponto de vista da expressão simbólica, o primeiro dos neoplatônicos não considera as funções masculina e feminina do mesmo modo que os indianos. Nos casais divinos, a figura feminina (Penía e Afrodite) é sempre associada a uma hipóstase hierarquicamente inferior àquela que é representada pela figura masculina (Poros, Zeus). ${ }^{33}$ Ademais, quando se trata da energia criadora que faz proceder a vida no mundo sensível, o princípio feminino e maternal é substituído pela figura platônica do demiurgo, ele mesmo engendrado pelo princípio. E quando Plotino evoca a matéria como "mãe" (cf. Timeu, 49a-51a), contraparte do logos (figurado por Hermes) e representada pela "mãe de todas as coisas" (Cibele) envolta de seres assexuados (os eunucos), ele precisa logo que ela não é uma mãe, pois ela recebe, mas não procria (En III, 6 [26], 19, 18-41). Estamos longe da figura do andrógino shivaísta, dessa complementaridade primitiva entre as funções masculina e feminina.

Todavia, alguns mitos cosmológicos e antropogônicos, nos quais encontramos o traço nos tratados herméticos, caldaicos, gnósticos ou, ainda, em citações órficas nos neoplatônicos tardios, exprimem a idéia da coincidentia oppositorum na totalidade divina, uma e indiferenciada, tendo recorrido à figura do andrógino ou do hermafrodita, concebido como o paradigma de um estado de indistinção que precede as classificações do mundo sensível. Nas rapsódias órficas citadas por Proclo e Damáscio, o ser bissexuado (Cronos, Fanes, Zeus, depois Dioniso) engendra cada vez as diferenças e as determinações por uma cisão cada vez mais elaborada, um jogo criador em que se produzem união e divisão. Alguns tratados gnósticos mostram que o demiurgo bissexuado dá lugar a vários grupos de sete entidades bissexuais (cosmo-teogonia), das quais sucedem um Adão (Adam) e um Eros bissexuados (antropogonia) - esses mitos exprimindo o ideal do monakhós, do eleito que escapa à duplicidade dos sexos. Os oráculos caldaicos qualificam o Intelecto primeiro de pai e mãe ao mesmo tempo, enquanto o Corpus Hermético caracteriza o Intelecto divino como "macho e fêmea" (arrenóthelus) em seguida ao qual ainda vêm vários seres bissexuais: o Homem arquétipo, os homens terrestres saídos de sua união com a Natureza, os sete planetas, depois os seres sensíveis durante um

33 Ver meu livro, L’amour chez Plotin. Erôs hénologique, érôs noétique, érôs psychique. Bruxelles, 1994, p. 43-64. 
período determinado, todos "machos e fêmeas" a partir dos quais se operam as divisões, entre as quais aquela dos sexos. ${ }^{34}$

Mencionando a existência de uma estátua entre os indianos que corresponde incontestavelmente à representação de Śiva Ardhanārīśvara, Bardesano e Porfírio também encontram idéias e representações míticas que pertenciam ao meio cultural e intelectual próprio deles. Na época, a tendência é o sincretismo ${ }^{35}$ e parece que nossos autores, apesar de desejarem descrever escrupulosamente a estátua indiana, não puderam impedir de introduzir elementos indianos nessa descrição. ${ }^{36}$

É o que ressalta de pelo menos duas características atribuídas à representação de Śiva andrógino. Por um lado, seus braços parecem abertos "à maneira de uma cruz" (en tupôi staurou, I. 33), o que, que eu saiba, não tem equivalente na iconografia indiana, mas parece antes corresponder à figura do Cristo. ${ }^{37}$ Por outro, a estátua, de acordo com Bardesano/Porfírio (I. 45-47), foi dada pelo deus supremo ao seu "filho" a fim de que ele se sirva dela como modelo (parádeigma) no momento da criação do kósmos. ${ }^{38}$

Para concluir, essa breve passagem constitui um traço importante e um exemplo interessante dos tipos de conhecimentos que se podia ter em Roma sobre as religiões da Índia. $\mathrm{O}$ fato de se tratar de um relato às vezes lendário e de um testemunho indireto (Porfírio lendo o relato de um encontro de Bardesano e diplomatas indianos) não impede uma grande precisão dos

34 Resumo aqui a apresentação e a exegese magistral desses textos por L. Brisson, Le sexe incertain. Androgynie et hermaphrodisme dans l'Antiquité, Paris, 1997, p. 78-92 (orphisme), 92-95 (gnosticisme), 95-97 (Oracles chaldaiques) e 97-102 (Corpus hermétique). Ver também M. Eliade, Méphistophéles ou l'androgyne, Paris, 1962, p. 149 sq.

35 "Tratados gnósticos, Oráculos caldaicos e tratados herméticos apresentam, entre eles, várias semelhanças marcantes. Um tal fenômeno parece dever se explicar menos por um empréstimo direto do que por uma dependência de necessidades análogas, notadamente aquela de assegurar sua salvação pessoal de modo definitivo e quase automático pelo conhecimento de doutrinas reservadas e por uma referência a um mesmo fundo intelectual caracterizando-se por um largo sincretismo em que o pensamento grego, permanecendo predominante, sofre várias influências estrangeiras - egípcia, iraniana e sobretudo judaica (L. Brisson, op. cit., p. 99).

36 Cf R. Reitzenstein e H.H. Schaeder, Studien zum antiken Synkretismus aus Iran und Griechenland, Munich, 1965, p. 91-92.

37 Esse elemento da descrição é verossimilmente devido ao próprio Bardesano. R. -P Droit (comunicação citada n. 3) tem razão em colocar a questão de saber se se trata de uma interpolação gnóstica.

38 Para Lassen, loc. cit., esse "filho" é Ganeśa. Mas o deus de cabeça de elefante, garantia de felicidade e de prosperidade, não é apresentado em nenhuma parte como o criador do mundo. Ademais, não existe nenhuma tradição que apresenta Brahma, o criador, como filho do deus supremo, aqui, Śiva. Então, é muito mais verossímil que estejamos na presença de uma cosmologia influenciada pelas concepções genealógicas da época e pelas interpretações do Timeu que distinguem um deus paterno e um demiurgo que é seu filho. Notamos ainda essa curiosa petição de princípio induzida pela introdução da noção de parádeigma a qual consiste em dizer que "tudo que existe" está gravado, representado sobre a estátua, enquanto esta é, ela mesma, o modelo, o arquétipo de todas as coisas (cf. comunicação de R. -P. Droit citada acima, n. 3). 
fatos relatados, em todo caso, quando a descrição se coloca em um contexto especificamente indiano. Sobre vários pontos, ele concorda com o que se diz, aliás, de Ardhanārīśvara e dos locais de culto shivaístas, mesmo se certos elementos do relato são difíceis de se identificar com precisão. A menção, em um discípulo de Plotino, de uma representação de unidualidade divina poderia ser explicada por afinidades ideológicas sem que se deva falar de "influências". Essa passagem desconhecida de Porfírio testemunha claramente, em todo caso, o interesse dos Romanos - e, nesse caso, de um dos primeiros filósofos neoplatônicos - pelo simbolismo religioso mitológico das religiões da Índia distante. 